Energy Technologies for the 21st Century-The Roles of Renewable Energy

R. N. Schock

August 2, 2005

World Federation of Scientists International Seminars on Planetary Emergencies Erice, Italy August 20, 2005 through August 23, 2005 
This document was prepared as an account of work sponsored by an agency of the United States Government. Neither the United States Government nor the University of California nor any of their employees, makes any warranty, express or implied, or assumes any legal liability or responsibility for the accuracy, completeness, or usefulness of any information, apparatus, product, or process disclosed, or represents that its use would not infringe privately owned rights. Reference herein to any specific commercial product, process, or service by trade name, trademark, manufacturer, or otherwise, does not necessarily constitute or imply its endorsement, recommendation, or favoring by the United States Government or the University of California. The views and opinions of authors expressed herein do not necessarily state or reflect those of the United States Government or the University of California, and shall not be used for advertising or product endorsement purposes. 


\title{
Energy Technologies for the 21st Century-The Roles of Renewable Energy
}

Robert N. Schock

\author{
Center for Global Security Research, Lawrence Livermore National Laboratory, University
}

of California, Livermore CA 94551

\begin{abstract}
Renewable energy sources, originating for the most part from the sun's radiant energy, are ubiquitous, long-lived, essentially free of carbon emissions, and have the potential to contribute significantly to mounting energy needs of the globe. In terms of percentage increase in installed capacity, renewable energy collectively is the fastest growing energy source. Even assuming that the developing world raises its standard of living considerably, the technical potential of renewable energies is more than enough to meet annual global needs several times over a century from now. Realizing even some of this potential involves overcoming obstacles in generation costs, proximity to markets, and in many cases intermittency, as well as others. From the perspective of work on a wide range of energy technologies by both the World Energy Council and the Intergovernmental Panel on Climate Change, the potential, timing, and investment costs for renewable energy technologies in the 21 st century have become clearer. The marketplace, based on cost and performance, will determine which technologies are commercialized along with government policies that at a minimum do not hinder their introduction, and - at a maximum - may encourage more rapid and successful introduction. A wide range of possible scenarios (34) based on factors that include energy availability, demographics, economic development, competition, environmental constraints, and most importantly technical learning, place some constraints on the range of possible energy requirements. Most scenarios indicate that renewable energy in total is likely to be as much as half the world's supply in 100 years, but most of that growth is expected in the period 50 to 100 years from now-if critical advancements and investments are made over the next 50 years.
\end{abstract}

\section{Introduction}

Renewable energy sources, for the most part originating from the sun's radiant energy, are ubiquitous, long-lived, and essentially free of carbon emissions. Renewable energy has the potential to respond to global sustainability and environmental, safety, social, and economic goals. Benefits of renewable energy systems are stated in a political declaration agreed to by 154 nations at the 2004 International Conference for Renewable Energies (2004), held in Bonn as a followup to the 2002 World Summit on Sustainable Development, held in Johannesburg. Benefits include energy-supply security, equity and development, improved health, overcoming peak oil-price fluctuations, the provision of clean water, neatly fitting with energy efficiency measures, and climate change mitigation.

Renewable energy sources include hydropower, modern biomass, solar, wind, geothermal, and ocean energy. Together, they currently contribute the equivalent of 7 percent of the world's primary energy use, not counting traditional biomass, which is not considered sustainable and amounts to another 7 percent (Table 1). Because 70 percent of this modern renewable energy is hydropower, the remaining sources contribute less than one percent. Nevertheless, renewable energy is the fastest growing energy sector in terms of percent annual increase. For the world to continue this rate of increase of overall use of renewable 
energy, a number of properties present challenges. These include an inherent low-energy density and low efficiency of conversion in many cases, and intermittent availability in some of the key areas of potential. Advanced efficient and inexpensive energy-storage technologies are would help a great deal with this latter challenge, and somewhat with the former.

Table 1. The world's energy reserves, resources, and use according to energy source An EJ (10 ${ }^{18}$ joules) is approximately equivalent to 23 billion barrels of oil or 32 trillion watt-years of electricity [from BP, World Energy Council (2004a), IEA, IAEA, International Renewable Energy Conference, and Johansson et al.].

\begin{tabular}{|c|c|c|c|}
\hline Class & Type & Est. Available (EJ) & $\begin{array}{c}\sim 03 \text { Rate (490 total) } \\
\text { (EJ/yr) }\end{array}$ \\
\hline \multirow[t]{6}{*}{ Fossil } & Oil (conventional) & 10,000 & 150 \\
\hline & Oil (unconventional) & 35,000 & 3 \\
\hline & Gas (conventional) & 18,000 & 160 \\
\hline & Gas (unconventional) & 68,000 & small \\
\hline & Coal (conventional) & 100,000 & 100 \\
\hline & $\begin{array}{l}\text { Coal } \\
\text { (unconventional) }\end{array}$ & 32,000 & 0 \\
\hline \multirow[t]{3}{*}{ Nuclear } & $U^{235}(\$ 130 / k g)$ & 5,800 & 25 \\
\hline & $\mathrm{U}^{238}$ and $\mathrm{Th}$ & $>400,000$ & very small \\
\hline & Fusion & $?$ & 0 \\
\hline \multirow[t]{6}{*}{ Renewable } & Hydro & $60 / y r$ & 25 \\
\hline & Wind & $600 / y r$ & $\sim 0.5$ \\
\hline & $\begin{array}{l}\text { Solar (PV and } \\
\text { thermal) }\end{array}$ & $1,600 / \mathrm{yr}$ & $\sim 0.2$ \\
\hline & Geothermal & $5,000 / y r$ & $\sim 2$ \\
\hline & Biomass & $250 / y r$ & $\sim 50(6)$ \\
\hline & Ocean & $\sim 10 / \mathrm{yr}$ & .002 \\
\hline
\end{tabular}

This paper reviews the present status of renewable energy and its potential to make significant contributions to future energy needs of the world. Concern about future energy supplies arises because of rapidly growing needs, driven by the developing world (Figure 1), in particular Asia, although Latin America and Africa also lag behind in both energy and economic level per capita and are expected to eventually catch up. As shown in Table 2, primary energy consumption may double in the next 30-50 years. [Note that although projected population may be a little high (10 billion instead of the present consensus 8 billion), GDP projections nicely bracket those forecasts]. In addition, there is the threat of rapid global climate change resulting from the use of fossil fuels that today constitute about 80 percent of the world's modern energy utilization (see Table 1). This fossil-fuel utilization presently adds about 7 billion tonnes of carbon to the atmosphere every year (Pacala and Socolow, 2004). 




Figure 1. World energy consumption (from BP Statistical Review of World Energy, 2005).

Table 2. Range of characteristics for 34 scenarios in 2050 and comparison with actual changes between 1800 and 2000 (from N. Nakicenovic, presented at World Energy Congress, Sydney, September, 2004).

\begin{tabular}{|l|c|c|c|c|c|} 
& 1800 & 2000 & $\Delta f$ & 2050 & $\Delta f$ \\
\hline Population (billion) & 1 & 6 & $\times 6$ & 10 & $\times 1.6$ \\
\hline GDP (trillion 1990 \$) & 0.3 & 30 & $\times 100$ & $85-110$ & $<\times 3-\times 4$ \\
\hline Primary energy (EJ) & 13 & 420 & $\times 30$ & $600-1,040$ & $\times 1.5-\times 2.5$ \\
\hline $\mathrm{CO}_{2}$ emissions (GtC) & 0.3 & 6.4 & $\times 20$ & $5-15$ & $<\times 1-\times 3$ \\
\hline Mobility (km/person/day) & 0.04 & 40 & $\times 1,000$ & $120-160$ & $\times 3-\times 4$ \\
\hline
\end{tabular}

It is useful to discuss scenarios of future of energy utilization as it forces thinking not only about a range of energy possibilities, but it also integrates the possible effects of a wide range of factors including energy availability, demographics, economic development, and perhaps most importantly technological change, especially in this case, the learning rates of new technologies (World Energy Council, 2001, 2004b). Examples of technological learning are shown in Figure 2. 




Figure 2. The effect of technological learning on the penetration rates of wind, ethanol, and solar photovoltaic technologies in terms of investment costs (from Johansson et al., 2004). A $P R=80 \%$ represents a $20 \%$ reduction in penetration rates per doubling of capacity.

\section{Current Utilization and Potential}

Pacala and Socolow (2004) introduced a useful way of thinking about solutions to the problem of reducing the addition of anthropogenic carbon into the atmosphere. They argue that the technology either exists or is being developed to stabilize greenhouse-gas emissions and they utilize a "wedge" as the activity beginning now such that one billion tonnes of carbon per year would not otherwise be added in 2054 to gradually reduce the rate of carbon buildup in the atmosphere over the intervening fifty years. Renewable electricity and fuels were assigned one of seven wedges. Pacala and Socolow suggested that this renewable wedge might be accomplished, for example, by making more electricity from wind and solar instead of coal, making hydrogen for use in fuel cell-powered vehicles from wind-generated electricity, and making liquid fuels from biomass. One wedge is the equivalent of replacing about 50 EJ of primary energy in 2050 from the mix of fossil fuels used in the world today (average $25 \mathrm{EJ} / \mathrm{yr}$ over the period).

Generally agreed upon potentials (both theoretical and technical) of renewable energy sources are shown in Table 3, along with their rates of use today (Johansson et al., 2004) indicating that the $36 \mathrm{EJ}$ of modern renewable energy use today is technically capable of achieving another 50 EJ in 50 years. The question is, "What might actually be achieved and what other factors influence the answer?" Economic cost, competition from the marketplace, future government policies, environmental constraints, and RD\&D investments comprise the major part of the answer. 
Table 3. Potential (EJ/yr) renewable energy sources and current use rates (from Johansson et al., 2004).

\begin{tabular}{|l|l|l|l|}
\hline Resource & $\sim$ Use rate (EJ/yr)* $^{*}$ & Technical & Theoretical \\
\hline Hydro & $10(25)$ & 50 & 150 \\
\hline Biomass E & $50(9)$ & $>250$ & 2,900 \\
\hline Solar & 0.2 & $>1,600$ & $3,900,000$ \\
\hline Wind & $0.2(0.5)$ & 600 & 6,000 \\
\hline Geothermal & 2 & 5,000 & $140,000,000$ \\
\hline Ocean & nil & 10 & 7,400 \\
\hline TOTAL & $62.4(36.4)$ & $>7,500$ & $>143,000,000$ \\
\hline
\end{tabular}

${ }^{*}$ Equivalent primary energy without traditional biomass and hydro at fossil efficiency

\section{Hydropower}

Large (10-MW) hydroelectricity systems account for $25 \mathrm{EJ} / \mathrm{yr}$ of global energy (BP, 2004), provide 17 percent of global electricity, and avoid releasing $0.6 \mathrm{GtC} / \mathrm{yr}$ of carbon into the atmosphere compared with the same amount of coal-fired power generation. Hydropower projects under construction will increase the electricity share by about 13 percent for a total electricity share of just under 20 percent (World Energy Council, 2004a). About 25 percent of water reservoirs in the world have associated generation facilities, but many more irrigation and urban water supply schemes could add hydropower generation. BP estimates there is the capability to produce $60 \mathrm{EJ}$ of energy from large hydropower systems (BP, 2004). Small hydropower systems $(<10 \mathrm{MW})$ have provided electricity to many rural communities in developing countries, such as Nepal, but in total generate only slightly less than $1 \mathrm{EJ} / \mathrm{yr}$ of power (World Energy Council, 2004a).

As a mature technology, hydropower has the advantage of being dispatchable, but it is currently burdened with environmental (river and stream aquatic life) and social (displacement of populations) issues. Also, the issue of intermittency has surfaced in Brazil during a period of prolonged drought in a region used to relying on significant rainfall and in California during periods of low mountain snowfall and subsequent runoff. Costs of hydrogenerated electricity currently center around 2 cents $/ \mathrm{kWh}$, but are estimated to be as high as 10 cents/kWh for some systems (Johansson et al., 2004).

\section{Biomass}

Available global annual biomass residues are estimated to contain around $100 \mathrm{EJ}$ of energy including $6 \mathrm{EJ} / \mathrm{yr}$ from municipal solid waste (World Energy Council, 2004a). Biomass sources include forest, agricultural, and livestock residues, short rotation forest plantations, specialist energy crops, municipal solid waste, and other organic waste streams. These are used as feedstock to produce solid fuels (chips, pellets, briquettes, logs), liquid fuels (biodiesel, bioethanol), and gaseous fuels (biogas, synthesis gas, hydrogen) (Sims, 2004). These fuels can then be converted via numerous routes to electricity, heat, transport fuels, chemicals, and materials. Co-firing of biomass with coal or gas and co-generation through combustion to generate useful heat and power are promising commercial options.

Developing countries consume a large but inefficient volume of low-grade traditional biomass in the form of firewood, dung, and charcoal (amounting to as much as 14 percent of 
global primary energy use) for heating and cooking (World Energy Council, 2004a). Modern biomass energy utilizes market forces to fully use what in the past would have been discarded as waste. Over 130 million tonnes of municipal solid waste, including plastics, are combusted annually, but much more is deposited in landfills, which in turn creates large amounts of methane. Municipal-solid-waste combustion or gasification is preferred if emissions can be minimized. Industry makes substantial use of biomass residues such as bark, reject logs, and black liquor in pulp and paper mills. Biochemical technologies can convert cellulose to sugars and glycerides, which in turn can be converted to bioethanol, biodiesel, hydrogen, and chemical intermediates in bio-refineries.

Progress has been remarkable (Johansson et al., 2004) and Sweden now obtains 25 percent of its energy supply from biomass (forestry waste for domestic and district heating) and expects to raise this to 40 percent by 2020. Issues arise around sustainable management (can it actually be achieved?), conversion efficiencies (typically much lower than fossil-fuel conversion), delivery costs from source to market, soil erosion from agricultural practices, and the use of chemical fertilizers. Present costs of delivered electricity range between 3-12 cents/kWh, costs for heat between 1-6 cents/kWh, and $\$ 8-25 / \mathrm{GJ}$ for liquid fuel, all of which at the low end are competitive today.

It is important to note that this area holds significant promise for technical improvement, in step with general advances in biotechnology. Research on artificial enzymes to hydrolyse biomass, on fermentation organisms to remove contaminants from synthesis gas, and produce cost-effective methods of drying, compacting, and transporting low-energydensity biomass residues is needed to take greater advantage of this resource. In addition, cutting edge research on imitating natural designs (biomimesis) for processes such as artificial photosynthesis or photon-induced decomposition of water hold great promise.

\section{Solar}

Energy radiating from the sun has enormous potential for heat and electricity production (see Table 3). The technical potential is three times present use today. Utilizing solar photons to create free electrons in a photovoltaic system today produces over $1 \mathrm{GWe}$. Solar thermal production of electricity using radiation heating produces slightly less than half that amount.

Commercially available solar photovoltaic modules are up to 18 percent efficiency and generate electricity for between 20 and 32 cents/kWh in high sunshine regions (U.S. Climate Change Technology Program, 2003). Experimental photovoltaic cells have laboratory efficiencies up to 37 percent (ibid.), but the investment cost is still very high. Work on reducing the cost of manufacturing, developing new materials such as quantum dots and nanostructures, and using low-cost polymer materials, will allow this resource to be more fully exploited. Commercial thin-film cells have efficiency in the range of 4-8 percent, but commercial efficiencies of 10 percent seem within reach during the next several years (RIS $\varnothing$, 2002). Costs of photovoltaic cell-produced power in the United States range from 45-76 cents/kWh (EPRI, 2005), although Johansson et al. (2004) quote figures as low as 25 cents/kWh worldwide.

High-temperature, solar-concentrated thermal power (CSP) generating plants are best sited in areas with high direct solar radiation, usually at lower latitudes. In these areas, one square kilometer of land is enough to generate $125 \mathrm{GWh} / \mathrm{yr}$ from a 50-MW plant (Philibert, 2004). Thus, about 1 percent of the world's desert areas could theoretically be sufficient to 
meet the world's electricity demand. The CSP plants are categorized as parabolic troughshaped mirror reflectors, central tower receivers using heliostats, or parabolic dish-shaped reflectors. Nine California power plants, connected to the Southern California grid during the period 1984-1991 have sizes in the range from 14 to $80 \mathrm{MW}$, with over 2 million square meters of parabolic troughs. Electricity from these sources at the buss bar costs 18 cents $/ \mathrm{kWh}$ (EPRI, 2005).

Not to be overlooked is the potential of passive solar power. Buildings can be designed to use efficient solar collection for passive space heating, heating water, and cooling using absorption chillers or desiccant regeneration (U.S. Climate Change Technology Program, 2003). In a typical mid-latitude temperate region, 30 percent of energy use is for space and water heating and is often around 50 percent of total building energy use with cooking and appliances making up the balance (World Energy Council, 2004a).

\section{Wind}

Wind can now be considered essentially a mature technology. At present, a little over $0.5 \mathrm{EJ} / \mathrm{yr}$ of wind energy is captured globally using $40 \mathrm{GW}$ of installed wind turbines (World Energy Council, 2004a). This has increased from $2.3 \mathrm{GW}$ of capacity in 1991 since new wind installations have been growing at an average of 25 percent/yr. The European Wind Energy Association recently published a target of $75 \mathrm{GW}(168 \mathrm{TWh})$ for the EU-15 countries in 2010 and $180 \mathrm{GW}$ (425 TWh) in 2020 (EWEA, 2004). The global wind energy resource is capable of several times the current total global demand for electricity.

The average size of wind turbines 25 years ago was less than $50 \mathrm{~kW}$, whereas the largest is now approaching $5 \mathrm{MW}$ with rotor diameters of 125 meters. The average turbine size is currently 1.6-2 MW. Higher mean annual wind speeds experienced offshore have led to the development of offshore wind farms that have the advantage of less public impact. Current capital costs for land-based wind turbine farms are about $\$ 900$ per installed $\mathrm{kW}$ and power is generated at 3-4 cents/kWh on good sites. Based on a learning rate experience of 15 percent cost reduction per doubling of installed capacity in Denmark since 1985, the cost of wind power should be $2.4-3.0$ cents/kWh by 2010 (Morthorst, 2004). Wind power is currently delivered to the buss bar at 4.5 to 6.5 cents/kWh in the United States (EPRI, 2005).

\section{Geothermal}

The present installed capacity of plants to convert geothermal heat to generate electricity is over $8,000 \mathrm{MWe}$ with an average production of $0.5 \mathrm{EJ} / \mathrm{yr}$ and a capacity factor averaging 70 percent (World Energy Council, 2004a). Over 10,000 MWe of proven resources are not yet utilized and it has been estimated that over 1,000 TWh/yr of electricity could be produced (World Energy Council, 2004a). There are some growing concerns relating to land subsidence and the long-term sustainability of a project if fluid and/or heat are extracted faster than it can be naturally replenished (Bromley and Currie, 2003). Geothermal heat is also used directly to provide industrial process heat and domestic water and space heating, most notably in Iceland and New Zealand where the hydrothermal resource is abundant. Several technologies are available to enhance the use of geothermal heat including combined cycle for steam resources, trilateral cycles for binary total-flow resources, and absorption-regeneration cycles (World Energy Council, 2004a). It is expected that improvements in characterizing underground reservoirs, low-cost drilling techniques, more efficient conversion systems, and utilization of deeper reservoirs, will improve the use 
of geothermal energy. Issues for technical improvement are low electrical conversion efficiencies and the release of gases to the atmosphere. Japan is testing ground-source heat pumps to increase conversion efficiencies. Costs of geothermal electric power are in the range of 5-6 cents/kWh at the buss bar in the United States (EPRI, 2005) and Johansson et al. (2004) quote figures worldwide as low as 2 cents $/ \mathrm{kWh}$.

\section{Oceans}

The ocean resource involves capturing the energy in wind-driven waves, ocean currents, the tides, or the temperature difference between warm surface water in tropical and sub-tropical latitudes and the colder water at depths of 1,000 meters or greater. The economically exploitable resource in deep-water waves using current device designs is estimated to be as great as $7 \mathrm{EJ} / \mathrm{yr}$ (World Energy Council, 2004a), while the theoretical potential is in the millions of EJ (see Table 3). Many wave devices are still in the R\&D stage with only a small number of devices tested or deployed in the sea. Extracting electrical energy from tidal currents is estimated to yield in excess of $10 \mathrm{TWh} / \mathrm{yr}(0.4 \mathrm{EJ} / \mathrm{yr})$ in each major estuary with large tidal fluctuations like the Bay of Fundy or the Solway Firth (World Energy Council, 2004a). Ocean thermal energy conversion is still in the research stage and it is too early to estimate the energy that might be recovered from this potential resource, but the initial application will likely be replacing expensive power from diesel generators in tropical island nations. Ocean current devices have been demonstrated off the coast of England. From a theoretical standpoint, ocean currents offer an immense source of renewable energy. From preliminary investigations for the Agulhas current off the coast of South Africa - the swiftest sea current in the world - it was estimated that on a 100-meter-deep seabed, a 1-km stretch of permanent turbines would produce $100 \mathrm{MW}$ (Nel, 2003). Costs of power from tidal fluctuations range from 8-15 cents/kWh (Johansson et al., 2004). One issue to be overcome in utilizing ocean resources for power is competition over rights to the use of the water (for example, fishing and recreation).

\section{Energy Storage}

There is little doubt that a major hindrance to the future penetration of renewable energy is the intermittent nature of much of it (wind, solar, ocean, hydropower), and that efficient and inexpensive energy storage technologies can play a very significant role in overcoming this obstacle. Such storage technology could become the tipping point to favor renewable energy. Where sites for natural reservoirs are limited and peak power demands are problematic, pumped water storage is being used and has potential for more. Power from a thermal generation facility or a wind farm is used to pump water up to a reservoir in off-peak hours, to be later converted into electricity by the pump acting as a turbine during periods of peak demand. Compressed gas is used in many places today to provide energy and heat storage. Lead acid and sodium-sulfur batteries are used by the high-tech industry to provide intermittent power and avoid any loss of power or power quality in the time between grid disruption and backup generator startup. Technologies that hold promise are flywheels made with high-tech materials (S-glass, Kevlar, carbon fiber) and with advanced bearings, reversible fuel cells, and hydrogen storage, among others. 


\section{Summary}

Renewable energy offers the promise of very large amounts of sustainable and safe energy. It is widely dispersed around the globe and can be utilized with relatively little environmental impact and almost no greenhouse-gas emissions. However, the energy density of these sources is typically low (lower than fossil energy and very much lower than nuclear energy) and conversion efficiencies can also be lower. This often, but not always, results in energy-cost differentials compared with fossil or nuclear fuels. Hydropower has always been the exception. Improvements in technology have brought the costs of other renewable energy sources down (in the case of wind to a competitive level) and internalizing many external costs has also tended to level the playing field somewhat. Solar photovoltaic, although very functional, is far from being competitive in large markets. Much renewable energy is also intermittent and until energy storage technology can be made cheap and very efficient, this resource is not likely to reach its full potential. There is little doubt that the world will use more renewable energy in the future and that the quantity will be influenced greatly by the research, development, demonstration, and deployment investments made now, as well as by external factors that influence the marketplace (political turmoil, government incentives, etc.). Global energy scenarios (Table 4) from both public and private organizations suggest a tripling and perhaps an order of magnitude increase over the next 50 years, depending on RD\&D investments made beginning now and marketplace competition and government policies between now and then.

Table 4. Scenarios of projected range of renewable energy contributions in 2050 (from Johansson et al., 2004).

\begin{tabular}{|l|l|l|l|}
\hline & Total (EJ) & Renewables & $\%$ ( 7 today) \\
\hline IIASA/WEC (6) (1998-2004) & $480-1040$ & $100-300$ & $20-40$ \\
\hline IPCC (40) (2000) & $640-1600$ & $73-444$ & $10-35$ \\
\hline Shell (2) (2001) & $850 / 1,200$ & $280 / 335$ & $33 / 28$ \\
\hline Goldemberg (2000) & 425 & 56 & 13 \\
\hline Johansson et al. (1993) & 510 & 240 & 13 \\
\hline
\end{tabular}

\section{Acknowledgments}

I am grateful for having benefited from useful discussions with many people. Especially useful are extended collaborations with William Fulkerson, Stephen Gehl, Nebojsa Nakicenovic, Bernhard Schlamadinger, Ralph Sims, and Yoshihiro Tachibana. I have heavily illustrated recent data in a publication by T. Johansson et al. (2004), but it is important to note that these data are very consistent with earlier data from a number of sources, some of which are quoted in this reference. This work was performed under the auspices of the U. S. Department of Energy by the University of California, Larwrence Livermore National Laboratory under Contract W-7405-Eng.48

\section{References}

BP Statistical Review of World Energy, 2005. 25th edition, London, www.bp.com, June (2005) 
Bromley and Currie 2003. C. J. Bromley and S. Currie, "Analysis of subsidence at Crown Road, Taupo: a consequence of declining groundwater," Proceedings of the 25th New Zealand Geothermal Workshop, Auckland University, pp. 113-120 (2003)

EPRI, 2005. S. Gehl, Electric Power Research Institute, Palo Alto, California, personal communication (2005)

EWEA, 2004. Wind energy-the facts-an analysis of wind energy in the EU-25, European Wind Energy Association, Brussels, www.ewea.org (2004)

International Renewable Energies Conference, 2004. Proceedings of the International Renewable Energies Conference (Internationale Konferenz für Erneuerbare Energien), Bonn, 1-4 June 2004, document available at www. renewables2004.de

Johansson et al. 2004. T.B. Johansson, K. McCormick, L. Neij, and W. Turkenburg, "The Potentials of Renewable Energy," Thematic Background Paper for Renewables, www.renewables2004.de (2004)

Morthorst, 2004. P.E. Morthorst, "Wind Power—status and perspectives," Future Technologies for a Sustainable Electricity System, Cambridge University Press, Tooraj Jamasb, William J. Nuttal, and Michael G. Pollitt, editors, ISBN: 05218604900 (to be published May 2006)

Nel, 2003. W. Nel, Feasibility of energy plant in Agulhas ocean current, Eskom Report No. RES/SC/03/22509, Eskom Holdings Ltd., Johannesburg (2003)

Pacala and Socolow, 2004. S. Pacala and R. Socolow, "Stabilization Wedges: Solving the Climate Problem for the Next 50 Years with Current Technologies," Science, Vol. 305, pp. 968-972 (2004)

Philibert, 2004. C. Philibert, "Case study 1: concentrating solar power technologies," International Energy Technology Collaboration and Climate Change Mitigation, OECD Environmental Directorate, IEA, Paris (2004)

Sims, 2004. R.E.H. Sims, "Biomass, Bioenergy, and Biomaterials-future prospects," Biomass and Agriculture: sustainability, markets, and policies, Organisation for Economic Cooperation and Development, June 2003, Vienna, pp. 37-61, ISBN: 92-64-10555-7 (2004)

RISØ, 2002. RISØ National Laboratory, Annual Report 2001, Roskilde, Denmark, www.risoe.dk (2002)

U.S. Climate Change Technology Program, 2003. www.climatetechnology.gov/library/2003/tech-options (2003)

World Energy Council 2001. Energy Technologies for the Twenty-First Century, World Energy Council, London, www.worldenergy.org/wec-geis (2001) 
World Energy Council 2004a. 2004 Survey of Energy Resources, World Energy Council, London, www.worldenergy.org/wec-geis (2004)

World Energy Council 2004b. Energy End-Use Technologies for the 21st Century, World Energy Council, London, www.worldenergy.org/wec-geis (2004) 